\title{
Correction to: Trading Off Tourism for Fisheries
}

\author{
Bui Bich Xuan ${ }^{1}$. Claire W. Armstrong ${ }^{2}$ \\ Published online: 25 September 2018 \\ (c) Springer Nature B.V. 2018
}

\section{Correction to: Environmental and Resource Economics https://doi.org/10.1007/s10640-018-0281-5}

During the correction stage, the author requested that " 302 be in line with $N P V^{*}$ and $N P V_{f}^{* \text { " }}$ in Table 4. However, adherence to Springer style prevented the particularities of this request to be fully carried out in the in the PDF versus the HTML versions of the article. To correct the issue, an update to the original article was made. The original article has been corrected.

The original article can be found online at https://doi.org/10.1007/s10640-018-0281-5.

$凶$ Bui Bich Xuan xuanbb@ntu.edu.vn

1 Economic Faculty, Nha Trang University, 02 Nguyen Dinh Chieu, Nha Trang, Vietnam

2 Norwegian College of Fishery Science, UiT The Arctic University of Norway, 9037 Troms $\emptyset$, Norway 